4th National Seminar on Guidance and Counseling (SNBK 2019) and Workshop on

Pedagogical Theory and Practice (WTPP 2019)

SHEs: Conference Series 2 (2) (2019) $98-109$

\title{
Penerapan Model Pembelajaran Kooperatif Tipe Scramble dalam Meningkatkan Motivasi dan Hasil Belajar Siswa
}

\author{
Dinah1, Yus Darusman², Fajar Nugraha $^{3}$ \\ 1,3 Universitas Perjuangan Tasikmalaya, ${ }^{2}$ Universitas Siliwangi \\ dinah.neng@gmail.com
}

\section{Article History}

accepted 2/11/2019

approved 23/11/2019

published 31/12/2019

\begin{abstract}
The problem in this study is the low student learning outcomes in social studies learning in Class V SD Negeri I Bojonggambir, Bojonggambir sub-district, Tasikmalaya Regency. The purpose of this study is to improve student learning outcomes in social studies learning material for the proclamation of Indonesian independence by using the Think, Pair, and Share (TPS) learning model in fifth grade students of SD Negeri 1 Bojonggambir, Kab. Tasikmalaya, 2018/2019 school year. The method used in this research is classroom action research (CAR). The results showed that there was an increase in social studies learning outcomes using Think, Pair, and Share learning models, the average student pre-action scores were 53.21, which reached 8 students (28.5\%) and had not yet reached 20 students $(71.4 \%)$. Cycle I increased by 8.21 with an average score of 60.71 , which reached 15 students (53.6\%) and 13 students (46.4\%) incomplete. Cycle II increased by 18.93 from cycle I, whereas when compared with pre-action it increased by 27.14 with an average score of 80.35 , completing 25 students (89.2\%) and 3 students (10.8\%) incomplete. The implication of this research is the use of Think, Pair, and Share (TPS) learning models on social studies learning for Indonesian independence proclamation material can improve student learning outcomes.
\end{abstract}

\section{Keywords: TPS, learning outcomes, social studies}

\begin{abstract}
Abstrak
Pendidikan pancasilan dan kewarganegaraan merupakan mata pelajaran yang didalamnya mendidik siswa agar menjadi warga negara yang patuh akan aturan yang telah ditetapkan, namun rata-rata siswa kurang termotivasi pembelajarann PPKn ini, mereka mengira bahwa pembelajaran PPKn membosankan, dan membutuhkan ,hapalan yang banyak.kurangnya motivasi siswa mengakibatkan hasil belajar siswa menurun. Penelitian ini bertujuan untuk menerapkan model pembelajaran kooperatif tipe sramble dalam meningkatkan motivasi dan hasil belajar siswa pada pembelajaran ppkn. Jenis penelitian ini adalah Penelitian Tindakan Kelas yang dilaksanakan dalam dua siklus. Teknik pengumpulan sampel yaitu dengan mengggunakan cara nonprobability sampling dengan teknik sampling purposive,. Metode pengumpulan data yag digunakan adalah tes hasil belajar, observasi, angket dan dokumentasi. penelitian menunjukan bahwa penggunaan model pembelajaran kooperatif tipe scramble pada pembelajaran PPKn yaitu 52 dari skor tertinggi 60 ( kategori tinggi ). Adapun skor akhir hasil belajar siswa mengalami kenaikan yang signifikan yaitu pada pra-siklus rata-rata nilai siswa 57 , 15 dari nilai 5 siswa yang tuntas dan 21 siswa tidak tuntas, sedangkan pada saat siklus I mencapai rata-rata 73,31 dari 11 siswa yang tuntas dan 10 siswa yang tidak tuntas sedangkan hasil siklus II yaitu dengan rata-rata nilai siswa 82,54 dari 18 siswa yang tuntas dan 5 siswa yang belum tuntas.
\end{abstract}

Kata Kunci: scramble, motivasi belajar , hasil belaja

Social, Humanities, and Education Studies (SHEs): Conference Series https://jurnal.uns.ac.id/shes

p-ISSN 2620-9284

e-ISSN 2620-9292 


\section{PENDAHULUAN}

Seiring dengan berkembangnya arus globalisasi, tantangan dunia pendidian pun menjadi semakin besar. Sekolah merupakan salah satu pendidikan formal yang didalamnya memiliki tanggung jawab yang besar dalam mendidik siswa supaya mereka mampu mengembangkan potensi dalam suatu ruang pembelajaran. Pembelajaran yang bagus merupakan pembelajaran yang dapat mebangun motivasi belajar siswa serta meningkatkan hasil belajar iswa. Motivasi menurut ahli psikologi Mc Donald dalam Hamalik (2015: 173) mengemukakan bahwa "Motivasi adalah suatu perubahan energi di dalam pribadi seseorang yang ditandai dengan timbulnya afektif dan reaksi untuk pencapai tujuan". Namun pada realitanya motivasi siswa terbangun tergantung keahlian guru dalam membawakan suatu pembelajaran. Kurangnya motivasi siswa dapat mengakibatkan menurunnya hasil belajar siswa. Afandi, et al ( 2013: 6 ) menyatakan bahwa: Hasil belajar merupakan proses perubahan kemampuan intelektual (kognitif), kemampuan minat atau emosi (afektif) dan kemampuan motorik halus dan kasar (psikomotor) pada peserta didik. Perubahan kemampuan peserta didik dalam proses pembelajaran khususnya dalam satuan pendidikan dasar diharapkan sesuai dengan tahap pekembangannnya yaitu pada tahapan operasional kongrit. Selain itu, pendidikan di sekolah dasar menanamkan keterampilan sosial. Hal ini merupakan sebuah bekal siswa untuk menyelesaikan perselisihan dalam interaksi dengan teman nya (Nugraha dan Zahrah, 2019).

Berdasarkan Observasi yang telah peneliti lakukan di SD Negeri 1 Sukamanah terdapat suatu permasalahan yang terdapat pada siswa kelas 4 . Permasalahan yang muncul yaitu kurangnya motivasi serta rendahnya hasil belajar siswa pada mata pelajaran PPKn, permasalahan tersebut dapat terlihat dari ketidakseriusan siswa serta tidak semanganya siswa dalam proses pembelajaran Kurangnya motivasi belajar siswa mengakibatkan nilai hasil belajar siswa rendah yaitu hanya siswa hanya 5 siswa yang di atas KKM dari 26 siswa. Alternatif yang prediksikan dalam penelitian ini yang diproyeksikan mampu memberikan motivasi yang tinggi serta proses pembelajaran bermakna yang akan menyebabkan meningkatnya hasil belajar siswa, adapun model pembelajaran yang akan diterapkan yaitu model pembelajaran kooperatif tipe scramble, yaitu suatu model pembelajaran yang dapat meningkatkan konsentrasi dan kecepatan berpikir siswa dalam menentukan suatu jawaban. Model yang akan digunakan dalam penelitian ini yaitu model pembelajaran kooperatif tipe scramble, menurut Shoimin ( 2017: 166) menyatakan bahwa : Scramble merupakan model pembelajaran yang mengajak siswa untuk menemukan jawaban dan menyelesaikan permasalahan yang ada dengan cara membagikan lembaran soal dan lembar jawaban yang disertai dengan alternative jawaban yang tersedia.

Adapun tujuan penelitian ini yaitu untuk mendeskripikan adanya perubahan aktifitas proses pembelajaran PPKn setelah diterapkan model pembelajaran kooperatif tipe scramble di kelas IV SD Negeri 1 Sukamanah juga untuk Mendeskripsikan adanya peningkatan motivasi dan hasil belajar siswa kelas IV SD Negeri 1 Sukamanah setelah menggunakan model pembelajaarn kooperatif tipe Scramble dalam membelajarkan mata pelajran PPKn.

\section{METODE}

Penelitian yang digunakan dalam penelitian ini yaitu penelitian yang berjenis PTK ( Penelitian Tindakan Kelas ) yang di dalam pelaksanannya memfokuskan pada keaktifan siswa yang dilaksanakan dalam dua siklus. Tindakan pada siklus I diawali dengan kegiatan perencanaan. Kegiatan perencanaan yang dilakukan meliputi:Menyusun RPP, membuat alat peraga, dan menyusun instrument penelitian.Tahap selanjutnya dilakukan tindakan yang sesuai dengan perencanaan tersebut. Tindakan ini dibagi menjadi tiga kegiatan, yaitu: (1) pendahuluan; (2) inti; dan 
(3) penutup. Pengamatan ini dilaksanakan berdasarkan pedoman observasi yang telah disusun. Berdasarkan hasil tersebut, dilakukan refleksi terhadap kegiatan pembelajaran yang berlangsung. Dengan demikian, ditemukan masalah apa saja yang menjadi kendala saat pembelajaran berlangsung serta untuk menangani kelemahankelemahan yang terjadi. Hasil refleksi tersebut kemudian dijadikan pedoman untuk memperbaiki proses pembelajaran pada siklus II apabila hasil yang diharapkan belum tercapai. Kegiatan siklus II ini merupakan perbaikan dari siklus I. Perbedaan kegiatan pembelajaran pada siklus I dan siklus II terletak pada kegiatan inti yang dilaksanakan pada saat tindakan. Pada siklus I, media scramble lebih besar shingga siswa dengan mudah menyusun jawaban yang telah tersedia serta pengaturan waktu yang lebih efektif

Peneliti dalam menghitung besarnya sampel dalam penelitian ini, yaitu mengggunakan nonprobability sampling dengan teknik sampling purposive, dimana dalam penggunaan teknik ini peneliti memilih sampel berdasarkan ciri-ciri tertentu yang berhubungan dengan masalah yang telah didapatkan. Subjek penelitian adalah siswa kelas VIA yang berjumlah 51 siswa (17 siswa laki-laki dan 34 siswa perempuan). Teknik pengumpulan data yaitu tes hasil belajar, observasi, angket dan dokumentasi. pembuatan lembar observasi dan angket yaitu dibuat menurut teori sklata liket, yaitu penilaian yang dari sangat positif sampai megatif. Adapun kisi-kisi motivasi dalam pembuatan lembar angket seagai berikut:

\section{Tabel 1 : Kisi-Kisi Motivasi Belajar Siswa}

\begin{tabular}{|c|c|c|}
\hline No & Indikator & Item Observasi \\
\hline 1 & $\begin{array}{l}\text { Kuatnya kemauan } \\
\text { untuk } \\
\text { berbuat }\end{array}$ & $\begin{array}{l}\text { 1. Siswa aktif memperhatikan penjelasan guru dalam } \\
\text { kegiatan pembelajaran. } \\
\text { 2. Siswa aktif bertanya kepada guru atau teman } \\
\text { mengenai materi yang belum dipahami }\end{array}$ \\
\hline 2 & $\begin{array}{l}\text { Jumlah waktu yang } \\
\text { disediakan untuk } \\
\text { belajar }\end{array}$ & $\begin{array}{l}\text { 3. Siswa mengerjakan tugas yang diberikan tepat waktu } \\
\text { 4. Siswa memanfaatkan waktu yang ada untuk } \\
\text { berdiskusi tentang pelajaran dengan teman maupun } \\
\text { dengan guru. }\end{array}$ \\
\hline 3 & $\begin{array}{l}\text { Kerelaan } \\
\text { meninggalkan } \\
\text { kewajiban atau tugas } \\
\text { yang } \\
\text { lain }\end{array}$ & $\begin{array}{l}\text { 5. Siswa aktif membaca buku untuk mencari sumber } \\
\text { jawaban yang benar dalam mengerjakan tugas di } \\
\text { kelas }\end{array}$ \\
\hline 4 & $\begin{array}{l}\text { Ketekunan dalam } \\
\text { mengerjakan tugas }\end{array}$ & $\begin{array}{l}\text { 6. Siswa aktif berdiskusi dengan teman-temen dalam } \\
\text { menyelesaikan tugas. } \\
\text { 7. Siswa tekun dalam mengerjakan tugas yang diberikan } \\
\text { guru }\end{array}$ \\
\hline 5 & $\begin{array}{l}\text { Ulet dalam } \\
\text { menghadapi } \\
\text { kesulitan }\end{array}$ & $\begin{array}{l}\text { 8. Siswa tidak mudah putus asa dalam mengerjakan } \\
\text { sesuatu di kelas } \\
\text { 9. Siswa tidak malu apabila mengalami kegagalan dan } \\
\text { mampu untuk bangkit lagi menjadi lebih baik }\end{array}$ \\
\hline 6 & $\begin{array}{l}\text { Menunjukkan minat } \\
\text { terhadap bermacam- } \\
\text { macam } \\
\text { masalah orang dewasa }\end{array}$ & $\begin{array}{l}\text { 10. Dalam mengerjakan soal atau mengerjakan tugas di } \\
\text { kelas, siswa dapat mengaitkan pelajaran dengan } \\
\text { kehidupan sehari-hari } \\
\text { 11. Siswa menunjukkan kepedulian terhadap teman- } \\
\text { temannya yang belum berhasil }\end{array}$ \\
\hline 7 & $\begin{array}{l}\text { Lebih senang bekerja } \\
\text { mandiri }\end{array}$ & $\begin{array}{l}\text { 12. Siswa berusaha mengerjakan tugas sesuai dengan } \\
\text { kemempuannya. } \\
\text { 13. Siswa percaya diri dalam melakukan sesuatu di kelas }\end{array}$ \\
\hline
\end{tabular}


4th National Seminar on Guidance and Counseling (SNBK 2019) and Workshop on

Pedagogical Theory and Practice (WTPP 2019)

SHEs: Conference Series 2 (2) (2019) 98-109

\begin{tabular}{|l|l|l|}
\hline No & \multicolumn{1}{|c|}{ Indikator } & \multicolumn{1}{c|}{ Item Observasi } \\
\hline & \multicolumn{1}{|c|}{ saat pelajaran } \\
\hline 8 & $\begin{array}{l}\text { Dapat } \\
\text { mempertahankan } \\
\text { pendapatnya }\end{array}$ & $\begin{array}{l}\text { 14. Siswa berani menyampaikan pendapat dalam forum } \\
\text { diskusi kelas } \\
\text { 15. Siswa mampu mempertahankan pendapatnya } \\
\text { beserta alasannya di hadapan teman yang lainnya. }\end{array}$ \\
\hline
\end{tabular}

Selain kisi-kisi lembar motivasi, terdapat juga kisi-kisi angket kesan penggunaan model dan kisi-kisi kesan belajar yaitu sebagai berikut :

Tabel 2: Kisi-Kisi Angket Kesan Menggunakan Model Pembelajaran Scramble

\begin{tabular}{|c|c|c|c|c|}
\hline $\begin{array}{l}\text { Variabel } \\
\text { Penelitian }\end{array}$ & Dimensi & Indikator & $\begin{array}{l}\text { No. } \\
\text { Item } \\
\text { Soal }\end{array}$ & Jumlah \\
\hline $\begin{array}{l}\text { Penerapan Model } \\
\text { Pembelajaran } \\
\text { Scramble untuk } \\
\text { Meningkatkan } \\
\text { Motivasi dan } \\
\text { Hasil Belajar } \\
\text { Siswa }\end{array}$ & $\begin{array}{l}\text { Penerapan } \\
\text { model } \\
\text { pembelajara } \\
\text { n scramble } \\
\text { pada materi } \\
\text { kewajiban } \\
\text { dan hak } \\
\text { sebagai } \\
\text { warga } \\
\text { masyarakat }\end{array}$ & $\begin{array}{l}\text { 1. Tanggapan siswa terhadap } \\
\text { penerapan model } \\
\text { pembelajaran scramble } \\
\text { 2. Penerapan model } \\
\text { pembelajaran scramble dapat } \\
\text { memotivasi siswa untuk belajar } \\
\text { 3. Penerapan model } \\
\text { pembelajaran scramble dapat } \\
\text { menciptakan hal yang baru } \\
\text { dalam materi hak dan } \\
\text { kewajiban } \\
\text { 4. Keaktifan siswa dalam kegiatan } \\
\text { pembelajaran dengan } \\
\text { penerapan model } \\
\text { pembelajaran scramble } \\
\text { 5. Pendapat siswa tentang } \\
\text { penerapan model } \\
\text { pembelajaran scramble pada } \\
\text { pokok bahasan hak dan } \\
\text { kewajiban sebagai warga } \\
\text { masyarakat } \\
\text { Keseriusan siswa terhadap } \\
\text { pembelajaran penerapan } \\
\text { model scramble } \\
\text { Efektifitas model pembelajaran } \\
\text { scramble terhadap } \\
\text { pembelajaran } \\
\text { 8. Pemahaman siswa pada pokok } \\
\text { bahasan kewajiban dan hak } \\
\text { sebagai warga masyarakat } \\
\text { dalam kehidupan sehari-hari } \\
\text { 9. Menambah pengetahuan siswa } \\
\text { 10. Guru dan siswa lebih interaktif } \\
\text { 11. Membuat siswa lebih banyak } \\
\text { bertanya } \\
\text { 12. Berbagi pengetahuan dengan } \\
\text { teman } \\
\text { 13. Dapat menjawab pertanyaan }\end{array}$ & $\begin{array}{r}9,10 \\
11,12 \\
13,14\end{array}$ & $\begin{array}{l}1 \\
1 \\
1 \\
1 \\
1 \\
1\end{array}$ \\
\hline
\end{tabular}


4th National Seminar on Guidance and Counseling (SNBK 2019) and Workshop on

Pedagogical Theory and Practice (WTPP 2019)

SHEs: Conference Series 2 (2) (2019) $98-109$

\begin{tabular}{|c|c|c|c|c|}
\hline $\begin{array}{l}\text { Variabel } \\
\text { Penelitian }\end{array}$ & Dimensi & Indikator & $\begin{array}{l}\text { No. } \\
\text { Item } \\
\text { Soal }\end{array}$ & Jumlah \\
\hline & & $\begin{array}{l}\text { guru } \\
\text { 14. Lebih menarik menggunakan } \\
\text { model pembelajaran scramble } \\
\text { 15. Penilaian proses belajar } \\
\text { kewajiban dan hak adanya } \\
\text { model pembelajaran scramble } \\
\text { 16. Melakukan diskusi secara aktif } \\
\text { antara sesama siswa dengan } \\
\text { guru } \\
\text { 17. Penerapan model } \\
\text { pembelajaran scramble dapat } \\
\text { meningkatkan hasil belajar } \\
\text { siswa pada pokok bahasan } \\
\text { kewajiban dan hak sebagai } \\
\text { warga masyarakat dalam } \\
\text { kehidupan sehari-hari }\end{array}$ & $\begin{array}{r}17,18 \\
25 \\
15\end{array}$ & $\begin{array}{l}1 \\
1\end{array}$ \\
\hline \multicolumn{3}{|c|}{ Jumlah Item } & 25 & 25 \\
\hline
\end{tabular}

Tabel 3: Kisi-Kisi Angket Kesan Belajar Siswa

\begin{tabular}{|c|c|c|c|c|c|}
\hline No & $\begin{array}{l}\text { Variabel } \\
\text { Penelitian }\end{array}$ & Dimensi & Indikator & $\begin{array}{l}\text { No } \\
\text { Butir } \\
\text { Soal }\end{array}$ & Jumlah \\
\hline 1 & $\begin{array}{l}\text { Penerapan Model } \\
\text { Pembelajaran } \\
\text { Scramble untuk } \\
\text { Meningkatkan } \\
\text { Motivasi dan Hasil } \\
\text { Belajar Siswa }\end{array}$ & Aktif & $\begin{array}{l}\text { 1. Keinginan, keberanian, } \\
\text { menampilkan bakat dan } \\
\text { menyelesaikan permasalahan } \\
\text { yang dihadapi } \\
\text { 2. Penampilan berbagai usaha } \\
\text { belajar dalam menjalanai dan } \\
\text { menyelesaikan kegiatan } \\
\text { belajar sampai mencapai } \\
\text { hasil } \\
\text { 3. Guru melakukan usaha } \\
\text { mendorong, membina gairah } \\
\text { belajar dan berpartisipasi } \\
\text { dalam proses pembelajaarn } \\
\text { secara aktif } \\
\text { Guru menggunakan metode } \\
\text { mengajar dan pendekatan } \\
\text { multimedia. }\end{array}$ & 3 & 1 \\
\hline 2 & & Inovatif & $\begin{array}{l}\text { 1. Siswa dapat menciptakan } \\
\text { pemahaman baru }\end{array}$ & $5-6$ & 2 \\
\hline 3 & & Kreatif & $\begin{array}{l}\text { 1. Berfikir divergen ( beragam } \\
\text { alternative pemecahan } \\
\text { masalah ) } \\
\text { 2. Fleksibelitas dalam bepikir ( }\end{array}$ & 7 & 1 \\
\hline
\end{tabular}


4th National Seminar on Guidance and Counseling (SNBK 2019) and Workshop on

Pedagogical Theory and Practice (WTPP 2019)

SHEs: Conference Series 2 (2) (2019) $98-109$

\begin{tabular}{|c|c|c|c|c|}
\hline & & $\begin{array}{l}\text { melihat dari berbagai sudut } \\
\text { pandang) }\end{array}$ & 8 & 1 \\
\hline 4 & Efektif & $\begin{array}{l}\text { 1. Siswa mampu } \\
\text { mengaplikasikan konsep } \\
\text { pada masalah sederhana } \\
\text { 2. Siswa termotivasi untuk giat } \\
\text { belajar }\end{array}$ & $\begin{array}{l}9 \\
10\end{array}$ & 1 \\
\hline 5 & $\begin{array}{l}\text { Menyenang } \\
\text { kan }\end{array}$ & $\begin{array}{l}\text { 1. Pembelajaran berlangsung } \\
\text { secara interaktif } \\
\text { 2. Pembelajaran berlangsung } \\
\text { secara gembira } \\
\text { 3. Pembelajaran berlangsung } \\
\text { dengan menimbulkan } \\
\text { inspiraasi }\end{array}$ & $\begin{array}{c}11 \\
12 \\
13-14\end{array}$ & 1 \\
\hline 6 & Gembira & $\begin{array}{l}\text { 1. menciptakan suasana } \\
\text { pembelajaran yang } \\
\text { menyenangkan }\end{array}$ & 15-16 & 2 \\
\hline 7 & Berbobot & $\begin{array}{l}\text { 1. Siswa dapat menguasai } \\
\text { materi sesuai dengan yang } \\
\text { diharapkan }\end{array}$ & $17-20$ & 4 \\
\hline \multicolumn{4}{|c|}{ Jumlah } & 20 \\
\hline
\end{tabular}

Untuk ketuntasan hasil observasi dan angket dilihat dari kriteria sebagai berikut :

$\begin{array}{ll}\text { Sangat Tinggi } & =85-100 \\ \text { Tinggi } & =65-84 \\ \text { Sedang } & =55-64 \\ \text { Rendah } & =35-54 \\ \text { Sangat Rendah } & =0-34\end{array}$

( Sumber: Afifa. 2017)

\section{HASIL DAN PEMBAHASAN}

\section{Hasil Penelitian}

Penelitian yang telah dilaksanakan merupakan penelitian tindakan kelas ( PTK) di kelas IVA yang dilakukan dalam dua siklus pada proses pembelajaran PPKn dengan menggunakan model pembelajaran kooperatif tipe scramble.. Dengan menggunakan metode PTK ini penelitian berjalan dengan mudah dalam pengumpulkan data-data dan penelitian lebih efektif. Model yang digunakan juga sangat pendukung dengan jenis penelitian ini. Model yang digunakan yaitu model pembelajaran scramble yang didalamnya siswa aktif, gembira dan mampu meningkatkan motivasi dan hasil belajar siswa serta mampu mengembangkan pemikirannya terhadap jawaban yang dipikirkan. Hasil data awal diperoleh dari hasil observasi dan data dari guru. Hasil awal motivasi hanya $58 \%$ dan kondisi awal hasil belajar siswa hanya 5 dari 26 orang siswa yang tuntas dengan jumlah rata-ratanya 57,15. Berikut data awal pra siklus sebagai berikut : 
4th National Seminar on Guidance and Counseling (SNBK 2019) and Workshop on

Pedagogical Theory and Practice (WTPP 2019)

SHEs: Conference Series 2 (2) (2019) 98-109

Tabel 4. Skor Hasil Belajar Siswa Kelas IVA pada Pra Tindakan

\begin{tabular}{|c|c|c|c|c|c|}
\hline No & KKM & $\begin{array}{c}\text { Jumlah } \\
\text { Siswa }\end{array}$ & $\begin{array}{c}\text { Jumlah } \\
\text { Nilai }\end{array}$ & $\begin{array}{c}\text { Presentase } \\
\%\end{array}$ & Keterangan \\
\hline $\mathbf{1}$ & Nilai $>75$ & 5 siswa & 421 & $19 \%$ & Tuntas \\
\hline $\mathbf{2}$ & Nilai $<75$ & 21 siswa & 1.065 & $81 \%$ & Tidak Tuntas \\
\hline \multicolumn{2}{|c|}{ Jumlah } & 26 & 1485 & $100 \%$ & \\
\hline \multicolumn{2}{|c|}{ Rata-Rata } & 57,15 & & \\
\hline
\end{tabular}

Berdasarkan hasil observasi peneliti pada pra siklus peneliti merencanakan proses tindakan siklus I untuk meningkatkan motivasi dan hasil belajar siswa.. pada pelaksanaan tindakan siklus I data kemampuan guru ( peneliti ) yaitu 91 pada kategori sangat tinggi. Pernyataan tersebut didukung dengan hasil angket kesan model dan kesan belajar. Adapun hasilnya yaitu 83 pada kategori tinggi pada kesan model dan 64 dari 80 dengan presentase $80 \%$ juga pada kategori tinggi. Adapun hasil motivasi yang diperoleh pada siklus I yaitu :

Tabel 5. Skor Motivasi Belajar Siswa Kelas IVA pada Siklus I

\begin{tabular}{|c|c|c|c|}
\hline No & Kategori Penilaian & Jumlah Aktivitas & Skor \\
\hline $\mathbf{1 .}$ & Sangat Baik (4) & 3 & 12 \\
\hline $\mathbf{2 .}$ & Baik (3) & 7 & 21 \\
\hline $\mathbf{3 .}$ & Cukup (2) & 5 & 10 \\
\hline $\mathbf{4 .}$ & Kurang (1) & 0 & 0 \\
\hline $\mathbf{5}$ & Sangat Kurang (0) & 0 & 0 \\
\hline \multicolumn{2}{|c|}{ Jumlah } & 43 \\
\hline \multicolumn{2}{|c|}{ Presentase } \\
\hline
\end{tabular}

Berdasarkan tabel 2 dapat dilihat bahwa terdapat kenaikan motivasi siswa yang pda pra siklus hanya 58\% dan pada siklus I menjadi $72 \%$. Kenaikan mencapai $14 \%$. Dari tindakan siklus I terdapat kenaikan yang cukup baik yaitu pada kategori tinggi, namun data tersebut belum cukup memenuhi keberhasilan penelitian yang sedang dilaksanakan. Selain motivasi belajar mengalami peningkatan, hasil belajarpun mengalami peningkatan yang signifikan. Adapun data hasil belajar pada siklus I yaitu sebagai berikut :

Tabel 5. Skor Hasil Belajar Siswa Kelas IVA pada Siklus I

\begin{tabular}{|c|c|c|c|c|c|}
\hline No & KKM & $\begin{array}{c}\text { Jumlah } \\
\text { Siswa }\end{array}$ & $\begin{array}{c}\text { Jumlah } \\
\text { Nilai }\end{array}$ & $\begin{array}{c}\text { Presentase } \\
\%\end{array}$ & Keterangan \\
\hline $\mathbf{1}$ & Nilai $>75$ & 11 Orang & $\mathbf{9 0 9 , 4 8}$ & $52 \%$ & Tuntas \\
\hline $\mathbf{2}$ & Nilai $<75$ & 10 Orang & $\mathbf{6 3 0 , 2 3}$ & $48 \%$ & Belum Tuntas \\
\hline \multicolumn{2}{|c|}{ Jumlah } & 21 & $1.539,71$ & $100 \%$ & \\
\hline \multicolumn{2}{|c|}{ Rata-Rata } & \multicolumn{2}{|c|}{73,31} & & \\
\hline
\end{tabular}

Berdasarkan data di atas, terdapat 11 orang atau 52\% siswa yang nilainya diatas KKM dengan rata-rata nilai semua mencapai 73,31. terdapat kenaikan atau peningkatan rata-rata skor akhir hasil belajar siswa dari yang pra-siklus 57,15 menjadi 73,31 pada siklus I naik 16,16 \%. Namum data tersebut belum mencapai peningkatan secara klasikal, dikarenakan siswa yang nilainya dibawah KKM masih terbilang banyak dan nilai hasil belajar siswa pun rendah.

Pada pelaksanaan siklus II data kemampuan guru ( peneliti ) yaitu 99 pada kategori sangat baik. Pernyataan tersebut didukung dengan hasil angket kesan model dan kesan belajar. Adapun hasilnya yaitu 90 pada kategori tinggi pada kesan model 
4th National Seminar on Guidance and Counseling (SNBK 2019) and Workshop on

Pedagogical Theory and Practice (WTPP 2019)

SHEs: Conference Series 2 (2) (2019) $98-109$

dan 71 dari 80 pada kategori tinggi pada kesan belajar. Data tersebut membuktikan kemampuan guru dalam membawakan pembelajaran sangat baik. . Adapun hasil motivasi yang diperoleh pada siklus II yaitu :

Tabel 6. Skor Motivasi Belajar Siswa Kelas IVA pada Siklus II

\begin{tabular}{|c|c|c|c|}
\hline No & $\begin{array}{c}\text { Kategori } \\
\text { Penilaian }\end{array}$ & Jumlah Aktivitas & Skor \\
\hline 1. & Sangat Baik (4) & 8 & 32 \\
\hline 2. & Baik ( 3) & 6 & 18 \\
\hline 3. & Cukup (2) & 1 & 2 \\
\hline 4. & Kurang (1) & 0 & 0 \\
\hline 5. & Sangat kurang (0) & 0 & 0 \\
\hline \multicolumn{2}{|c|}{ Jumlah } \\
\hline \multicolumn{2}{|c|}{ Presentase } \\
\hline
\end{tabular}

Berdasarkan tabel 4 dapat dilihat bahwa terdapat kenaikan motivasi siswa yang signifikan dan dalam kategori tinngi yaitu dengan skor $88 \%$. Peningyang tersebut mengalami kenaikan $16 \%$ dari siklus I. Data tersebut membuktikan bahwa motivasi belajar siswa dapa pembelajaran PPKn mengalami peningkatan yang cukup baik. Adapun data hasil belajar siswa pada siklus II sebagai berikut :

Tabel 7. Skor Hasil Belajar Siswa Kelas IVA pada Siklus II

\begin{tabular}{|c|c|c|c|c|c|}
\hline No & KKM & $\begin{array}{c}\text { Jumlah } \\
\text { Siswa }\end{array}$ & $\begin{array}{c}\text { Jumlah } \\
\text { Nilai }\end{array}$ & $\begin{array}{c}\text { Presentas } \\
\mathbf{e} \\
\%\end{array}$ & Keterangan \\
\hline $\mathbf{1}$ & $\begin{array}{c}\text { Nilai }> \\
75\end{array}$ & 18 Orang & $1.556,44$ & $78 \%$ & Tuntas \\
\hline $\mathbf{2}$ & $\begin{array}{c}\text { Nilai }< \\
75\end{array}$ & 5 Orang & 342,14 & $22 \%$ & Tidak Tuntas \\
\hline \multicolumn{2}{|c|}{ Jumlah } & 23 & $1.898,58$ & $100 \%$ & \\
\hline \multicolumn{2}{|c|}{82,54} & & \\
\hline
\end{tabular}

Berdasarkan data tabel di atas, hasil belajar siswa mengalami peningkatan secara klasikal yaitu dengan rata-rata skor 82,54 dengan 18 orang atau $78 \%$ siswa yang nilainya di atas 75.. Dibandingkan dengan siklus I yang hanya 73,31 dengan 11 orang atau $52 \%$, yang tuntas, siklus II mengalami peningkatan yang cukup baik yaitu $9,23 \%$. Maka dari data yang telah di anlisis, penelitian siklus II sudah mencapai target secara klasikal meski terdapat 5 siswa yang belum tuntas, tetapi skor yang didapat di siklus II meningkat lebih tinggi .

\section{Pembahasan}

Penelitian yang telah dilaksanakan merupakan penelitian tindakan kelas ( PTK) di kelas IVA yang dilakukan dalam dua siklus pada proses pembelajaran PPKn dengan menggunakan model pembelajaran kooperatif tipe scramble. Berdasarkan teori yang dikemukakan oleh Arikunto,dkk ( 2015: 1-2) menyatakan bahwa :Penelitian tindakan kelas adalah penelitian yang memaparkan terjadinya sebab-akibat dari perlakukan, sekaligus memaparkan apa saja yang terjadi ketika perlakkan diberikan, dan memaparkan seluruh proses sejak awal pemberian perlakukan sampai dengan dari perlakukan tersebut. Berdasarkan data hasil penelitian yang telah diperoleh, penerapan model pembelajaran scramble dalam pembelajaran PPKn menjadikan nilai hasil belajar siswa baik dan mengalami peningkatan. Hal tersebut dilihat dari hasil 
peningkatan aktivitas proses pembelajaran, motivasi serta hasil belajar siswa dari prasiklus ke siklus I sampai ke siklus II.

Dengan menggunakan metode PTK ini penelitian berjalan dengan mudah dalam pengumpulkan data-data dan penelitian lebih efektif. Pembelajaran yang baik merupakan suatu pembelajaran yang dapat membangun motivasi serta hasil belajar siswa lebih meningkat. Guru merupakan pasilitator dalam proses pembelajaran di kelas, yang menjadi panutan serta cerminan siswa-siswinya. Berhasilnya suatu pembelajaran tentunya dilihat dari seberapa besarnya kreatifitas seorang guru serta kepropesionalan guru dalam menyalurkan pengetahuannya kepada siswa. berdasarkan teori yang telah dikemukakan oleh Winkel dalam Siregar dan Hartini (2010: 12) penyetakan bahwa : Pembelajaran adalah seperangkat tindakan yang direncanakan untuk mendukung proses belajar siswa, dengan memperhitungkan kejadian-kejadian ekstrim yang berperan terhadap rangkaian kejadian-kejadian intern yang berlangsung dialami siswa.

Maka dengan itu, untuk membangun suatu pembelajaran yang bermakna serta menjadikan motivasi yang tinggi terhadap siswa, peneliti menyusun susunan pembelajaran yang menarik serta tidak membuat jenuh siswa, yaitu dengan menggunakan model pembelajaran kooperatif tipe scramble. Model pembelajaran kooperatif tipe scramble merupakan model pembelajaran yang sangat efektif digunakan dalam membangun serta meningkatkan motivasi dan hasil belajar siswa. pernyataan tersebut didukung oleh teori yang dikemukakan oleh Ariyanto ( 2016 ) menyatakan bahwa : Model pembelajaran screamble adalah model pembelajaran dengan cara berkelompok dengan mengasah kekreatifitasan siswa untuk mencari jawaban-jawaban logi dari kata-kata yang diacak dan siswa diminta merangkai menjadi jawaban yang logis dari sebuah pertanyaan atau persoalan. Penggunaan model tersebut membuat kepenasaran siswa dalam menjawab pertanyaan semakin meningkat, hal tersebut membuat semangat siswa dalam belajar meningkat.

Berdasarkan data yang diperoleh dari data observasi, angket dan tes hasil belajar siswa, maka data yang diperoleh bahwa kemampuan guru atau peneliti dalam menerapkan model pembelajaran kooperatif tipe scramble pada pembelajaran PPKn yaitu pada siklus I dengan skor 91 dan siklus II dengan skor 99, dari data tersebut mengalami kenaikan yang tinggi dan hampir mencapai skor yang sempurna, dan tergolongkan dalam kriteria penskoran sangat tinggi. . Hal tersebut didukung dengan respon tinggi siswa terhadap kesan pembelajaran yang telah guru laksanakan dalam pembelajaran PPKn, adapun hasil yang diperoleh yaitu bahwa skor akhir respon siswa terhadap kesan belajar mengalami peningkatan yang signifikan yaitu pada siklus satu hanya memperoleh 64 dari skor maksimal 80 dengan presentase $80 \%$ kategori tinggi dan pada siklus II pada kategori sangat tinggi dengan skor 71 dari skor maksimal 80 dengan presentase $88 \%$. Maka dengan itu pembelajaran PPKn yang telah dilaksanakan dalam penelitian dengan menggunakan metode PTK melalui penerapan model pembelajarn kooperatif tipe scramble sudah mencapai keberhasilan pembelajaran berstandarkan paikem gembrot, yaitu suatu pembelajaran aktifan, inovatif, kreatif, evaluative, menyenangkan, gembira berbobot dalam proses pembelajaran yang didalam proses pembelajrannya melibatkan keaktifan, kesungguhan serta membangun motivasi yang tinggi.

Pernyataan tersebut dapat diperkuat dengan pembuktian hasil respon siswa dalam pembelajaran menggunakan model pembelajaran kooperatif tipe scramble dalam pembelajaran PPKn bahwa respon siswa terhadap penggunaan model pembelajaran kooperatif tipe scramble dalam proses pembelajaran sangat baik. Hal tersebut dapat terlihat dari peningkatan yang tinggi dari siklus I dengan skor nilai 83 pada kategori tinggi dan siklus II dengan skor nilai 90 pada kategori sangat tinggi. Dengan itu guru atau peneliti berhasil dalam membelajarkan model kooperatif tipe 
scramble dalam kelas pada pembelajaran PPKn. Dengan data tersebut Membuktikan bahwa model pembelajaran kooperatif tipe scramble saat di terapkan di kelas IVA membuat motivasi dan hasil belajar siswa meningkat. Peningkatan motivasi dan hasil belajar dari pra siklus hingga siklus II sangat signifikan, adapun peningkatan tersebut dapat terlihat dari diagram sebagai berikut :

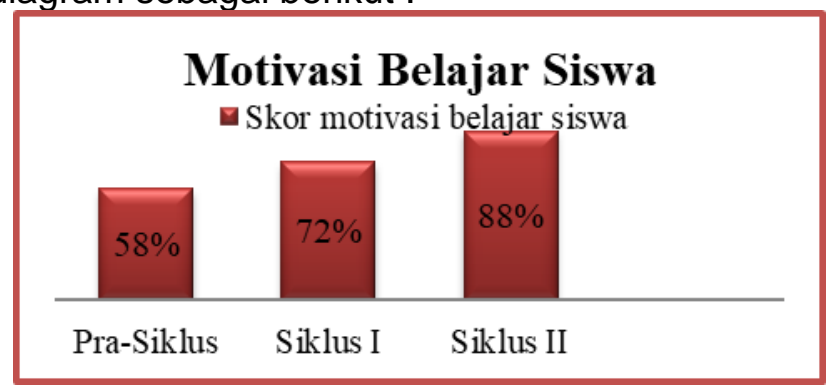

Gambar 1. Diagram Motivasi Belajar

Berdasarkan diagram motivasi diatas, maka dapat disimpulkan bahwa peningkatan motivasi belajar siswa pada pembelajaran PPkn dengan menggunakan model pembelajaran kooperatif tipe scramble sangat meningkat tinggi .dapat dilihat presentase awal pada sebelum diberi tindakan atau pra-siklus skornya $58 \%$ pada kategori rendah, selanjutnya pada siklus I $72 \%$ pada kategori sedang dan pada seklus II meningkat tinngi $88 \%$ pada kategori tinggi. Peningkatan yang terlihat sangat signifikan yaitu terdapat kenaikan $14 \%$ dari pra-siklus ke siklus I, dan $16 \%$ dari siklus I ke siklus II.

peningkatan motivasi belajar siswa yang terlihat dalam proses pembelajaran secara keseluruhan sebagai berikut secara:

1. Keberanian siswa untuk bertanya meningkat baik dalam kegiatan tanya jawab maupun dalam kegiatan diskusi kelompok

2. Konsentrasi siswa dalam proses pembelajaran sangat baik dapat terlihat pada hasil belajar siswa

3. Kerjasama tim dalam kelompok sangat terlihat ( tidak terdapat lagi siswa yang acuh terhadap tugas kelompok)

4. Kepercayadirin siswa dalam mengerjakan sesuatu terlihat sangat tinggi baik itu dalam pengerjaan tugas kelompok maupun tugas individu

5. Selain motivasi belajar meningkat, hasil belajar siswa pun meningkat, Adapun data peningkatan hasil belajar sebagai berikut:

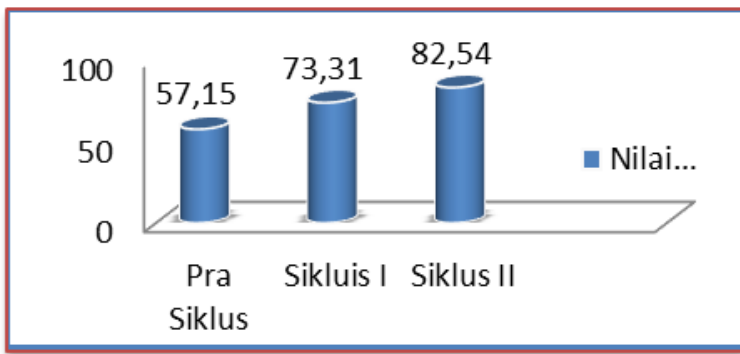

Gambar 2. Diagram Peningkatan Rata-Rata Nilai 


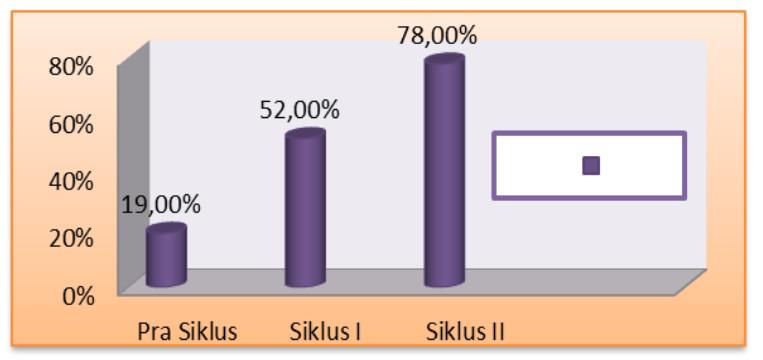

\section{Gambar 3. Diagram Peningkatan Siswa yang Tuntas}

Berdasarkan data diagram pada gambar 4.5 dan 4.6, bahwa nilai rata-rata siswa dari pra-siklus yang tidak diberi tindakan dengan siklus I yang telah diberi tindakan serta ke siklus 2 mengalami peningkatan yang cukup tinggi. Peningkatan ratarata nilai $16,16 \%$ dari pra-siklus ke siklus I dan $9,23 \%$ dari siklus I ke siklus II , maka dengan ini peneliti tidak dilanjutkan ke siklus berikutnya. Berdasarkan pernyataan tersebut maka penelitian yang telah dilaksanakan sudah mencapai peningkatan yang baik yaitu dengan peningkatan $25,38 \%$.

\section{SIMPULAN}

Berdasarkan rumusan hasil penelitian dan pembahasanmaka dapat disimpulkan bahwa model pembelajaran kooperatif tipe scramble dapat meningkatkan motivasi dan hasil belajar siswa kelas IVA SD Negeri 1 Sukamanah pada pembelajaran PPKn pada materi kewajiban dan hak sebagai Warga Negara Motivasi belajar yang terlihat pada siklus 1 mencerminkan tingkat keseriusan belajar siswa naik, namun ketuntasan belajar kurang muncul sehingga pembelajaran diperbaiki pada siklus II. Pada siklus II motivasi belajar siswa sangat naik, semangat belajar siswa membuat proses pembelajaran sangat bermakna serta menghasilkan hasil yang meningkat.

Adapun hasil belajar siswa mengalami peningkatan yang signifikan yaitu dapat terlihat dari nilai rata-rata siswa pada pra-siklus hanya 57,15 dari nilai 5 atau $19 \%$ siswa yang nilainya di atas KKM, , sedangkan pada saat siklus I mencapai rata-rata 73,31 dari 11 atau $52 \%$ siswa yang nilainya atas $\mathrm{KKM}$, adapun data hasil siklus II mengalami kenaikan yang lumayan tinggi yaitu dengan rata-rata nilai siswa 82,54 dari 18 atau $78 \%$ siswa yang nilainya di atas KKM. Berdasarkan data tersebut, maka nilai hasil belajar siswa sudah mencapai peningkatan secara signifikan yaitu 16,16\% dari pra-siklus ke siklus I dan 9,23\% dari siklus I ke siklus II, maka dengan itu penelitian yang telah dilakukan di kelas IVA SD Negeri 1 Sukamanah dengan penggunakaan model pembelajaran kooperatif tipe scramble dalam meningkatkan motivasi dan hasil belajar siswa pada pembelajaran PPKn ( kejawiban dan hak sebagai warga negara) dikatakan berhasil dengan peningkatan $25,39 \%$.

\section{DAFTAR PUSTAKA}

Afandi, Muhamad, et al. ( 2013 ). Model dan Metode Pembelajaran di Sekolah. Semarang :Unissula Press

Arikunto, Suharsimi. ( 2015 ) . Dasar-Dasar Evaluasi Pendidikan. Jakarta: TP Bumi Aksara.

Ariyanto, Metta. ( 2016 ). Peningkatan Hasil Belajar IPA Materi Kenampakan Rupa Bumi Menggunakan Model Scramble : Profesi Pendidikan Dasar, Vol 3, No 2, pISSN 2406-8012. Semarang: Universitas Kristen Satya Wacana

Hamalik, Oemar. ( 2015 ). Psikologi Belajar \& Mengajar.Bandung: Sinar Baru Algensindo 
Hernawan, Asep Heri, dan Rudi, Susulana. ( 2009 ). Kurikulum dan Pembelajaran. Bandung : Upi Press

Huda, Miftahul. ( 2017 ). Model-Model Pengajaran dan Pembelajaran. Yogyakata: Pustaka Pelajar

Husdarta, JS. dan Yudha, M., Saputra. ( 2013 ). Belajar dan Pembelajaran. Bandung: Alfabeta

Komara, Endang. ( 2012 ). .Penelitian Tindakan Kelas dan Peningkatan Profesionalitas Guru. Bandung :PT Rafika Aditama.

Nugraha, F. Zahrah, R, F. (2018). Permainan Tradisonal "Kaulinan Barudak" Untuk Meningkatkan Kemampuan Bersikap Empati Siswa Kelas V Sekolah Dasar. Jurnal Visipena Vol. 9. No. 2

Rusman. ( 2013 ). Belajar dan pembelajaran berbasis Komputer. Bandung: Alfabeta

Sanjaya, Wina. ( 2009 ) . Kurikulum dan Pembelajaran. Jakarta: Kencana Prenada Media Group

Shoimin, Aris. ( 2017 ). 68 Model Pembelajaran Inovatif dan Kurikulum 3013. Yogyakarta: Ar-ruzz Media

Siregar, Eveline \& Hartini, Nara. 2010. Teori Belajar dan Pembelajaran.Bogor :Ghalia Indonesia

Suprihatin, Siti. ( 2015 ) . Upaya Guru dalam Meningkatkan Motivasi Belajar: Jurnal Pendidikan Ekonomi UM Metro, Vol 1. No 3. Hal 73-82. P 2442-9449. Metro: Universitas Muhammadiyah Metro

Suyono, \& Hariyanto. ( 2016 ) . Belajar dan Pembelajaran. Bandung : PT Remaja Rosdakarya 